\title{
Peripheral T-Cell Lymphoma: Clinicopathologic Analyses of 25 Cases
}

\author{
Kazuyuki SHIMIZU, Tetsuro NAGASAKA*, Kazuo HARA**, \\ Kazunori OHNISHI***, Masami HIRANO and Akira KUNII****
}

\begin{abstract}
Twenty-five patients with peripheral T-cell lymphoma (PTCL) were analyzed to assess clinicopathologic features of the disease and were classified according to the newly proposed histologic classification for T-cell lymphomas to study the correlation between histology and survival, if any. Histologic diagnoses were: Lennert's, 1; T-zone, 1; pleomorphic, small, 1; pleomorphic, large, 1; angiocentric, 4; pleomorphic, medium, 5; immunoblastic, 5; angioimmunoblastic, 7. Patients with PTCL were noted to be endowed with clinicopathologic factors known to adversely affect survival, such as advanced stage $(92 \%)$, B symptoms $(56 \%)$, liver involvement $(56 \%)$, multinodal disease $(52 \%)$, elevated serum LDH $(48 \%)$, and so on. Response to therapy was poor. CR was obtained in $30 \%$ of patients with advanced disease with a $50 \%$ relapse rate. Median survival for the 25 patients was 13 months. No correlation was found between morphologic subtypes and survival.
\end{abstract}

Key words: Peripheral T-cell lymphoma, Histopathology, Clinicopathology, Adult T-cell leukemia lymphoma, Immunoblastic lymphadenopathy (IBL)-like T-cell lymphoma, Prognostic factors

The poorer prognosis of patients with nonHodgkin's lymphoma (NHL) in Japan in comparison with those in Western countries has been attributed to a higher incidence of T-cell lymphomas (1). In fact, whereas the incidence of T-cell lymphoma in Japan has been as high as $75 \%$ in endemic (2) and $40 \%$ in nonendemic (3) areas, NHL of T-cell derivation in Western countries (4) accounts only 10 to $20 \%$ of all NHLs. T-cell lymphomas in Japan, however, comprise heterogeneous clinicopathologic entities and are known for the prevalence of peripheral T-cell lymphoma (PTCL) (5). PTCL, defined as NHL with markers of mature T-cells but without clinicopathologic features of chronic lymphocytic leukemia, mycosis fungoides or Sézary's syndrome (6), has not been well delineated. It is because PTCL is quite heterogeneous clinicopatho- logically and also because PTCL outside Japan is rather uncommon entity. Whereas some PTCLs such as adult T-cell leukemia lymphoma (ATLL) (7) and immunoblastic lymphadenopathy (IBL)-like T-cell lymphoma (8) have been extensively studied in Japan, others such as Lennert's lymphoma (9) and T-zone lymphoma (10) have been recognized and defined in Western countries. Emergence of new clinicopathologic entities from all over the world, some of which can not be classified within the criteria of the working formulation for clinical usage (11), permits proposals of many rival histopathologic classifications of PTCL and has caused much confusion.

In the present report, we describe the clinicopathologic features along with immunophenotypes of PTCL diagnosed and treated at one of the

From Department of Medicine, Fujita Gakuen Health University School of Medicine, *Department of Pathology, Nagoya University Hospital, **The First Department of Pathology, Aichi Medical College, ***The First Department of Internal Medicine, Nagoya University School of Medicine and ****Department of Medical Technology, Nagoya University Received for publication December 24, 1988.

Reprint request to: Kazuyuki Shimizu, MD, Department of Medicine,

Fujita Gakuen Health University School of Medicine, Toyoake, Aichi 470-11, Japan 
university hospitals in Nagoya which is located in central Japan and is not known for the presence of any endemic lymphoma. We would also try to classify our cases according to the newly proposed histopathologic classification of T-cell lymphoma by Suchi, et al (12), and try to see if there would be any clinicopathologic correlation.

\section{MATERIALS AND METHODS}

\section{Study group}

Between January 1981 and September 1986, 87 previously untreated patients were diagnosed, worked-up and treated as NHL at First Department of Internal Medicine, Nagoya University Hospital, in Nagoya. Among the 87 patients, 25 were immunophenotypically identified as having T-cell lymphoma with the use of either E-rosetting or indirect immunofluorescent technique employing various monoclonal antibodies, or both. The current analysis was performed in November 1988. Follow-up time was calculated from the initiation of treatment, with a mean follow-up of 23 months and a range of 3 to 82 months.

Twenty-five patients with T-cell lymphoma were composed of 19 male and 6 female patients with male to female ratio of $3.2: 1$, with a median age at diagnosis of 55 years and an age range of 29 to 78 years.

Patients were staged according to the Ann Arbor classification (13). Pretreatment staging studies included complete blood count, routine liver function chemistries, chest radiograph, lymphangiogram, computed tomographic (CT) scan of the chest and abdomen, ${ }^{99 \mathrm{~m}} \mathrm{Tc}$ sulfur colloid liver and spleen scan, ${ }^{67} \mathrm{Ga}$ scan and bone marrow examination. In some selected patients, biopsy of the skin and the stomach, thoracocentesis, and percutaneous. liver biopsy was performed.

Of the 25 patients, only 2 patients $(8 \%)$ had localized disease (IA and IIA each) and the remaining 23 patients $(92 \%)$ had advanced disease ( 3 IIIA, 1 IIIB, 6 IVA and 13 IVB). In 5 patients $(20 \%)$, the primary lesion was considered to be extranodal: nose, 2; paranasal sinus, 1; upper palate, 1; and Waldeyer's ring, 1. Extranodal sites of involvement in 19 stage IV patients were as follows: liver in 14 patients; bone marrow, 5; peripheral blood, 5; pleura, 4; soft tissues, 4; and skin, 3.
Twelve of the 19 stage IV patients had involvement of more than one extranodal sites.

Histopathologic diagnoses were made according to the criteria by Suchi et al (12) and by Jaffe (6). Tables 1(a) through (c) show clinicopathologic features of the 25 patients with PTCL.

\section{Immunophenotypic studies}

Surface marker analyses were performed on the lymphoma cells obtained from lymph node biopsy specimens. Spontaneous rosette formation with 2-aminoethyl isothiouronium bromide hydrobromide (AET) treated sheep erythrocytes (E-rosette) was performed at $4^{\circ} \mathrm{C}$ and $37^{\circ} \mathrm{C}$ according to the method of Kaplan and Clark (14). Membrane differentiation antigens of lymphoma cells were detected by the indirect immunofluorescent techniques using various monoclonal antibodies (Leu-1, 2a, 3a, 4, 7 and HLA-DR, Becton-Dickinson, Mountain View, CA; B1, Coulter, Hialeah, FL; OKT 3, 4, 6, 8, 9 and 10, Ortho Pharmaceutical Corp. Raritan, NJ). As a second antibody, FITCconjugated goat $\mathrm{F}\left(\mathrm{ab}^{\prime}\right)_{2}$ anti-mouse IgG (Cappel, Cochranville, PA) was used. The percentage of reactive cells in at least 200 lymphocytes was determined under an Olympus BHF-ultraviolet microscope.

\section{Treatment}

In 22 out of the 25 patients, initial treatment was "weekly CHOP" which had been developed by us (15) and which was composed of weekly administration of cyclophosphamide $450 \mathrm{mg} / \mathrm{m}^{2}$, doxorubicin $20 \mathrm{mg} / \mathrm{m}^{2}$ and vincristine $1 \mathrm{mg} /$ body. In the remaining 3 patients, local irradiation followed by adjuvant "weekly CHOP" was given to 2 (stage I and II patients, each), and oral cyclophosphamide, 6-mercaptopurine and prednisolone were given daily to another one.

\section{Definition of response}

Patients who appeared in a clinical complete remission (CR) were reevaluated for evidence of residual tumor by repetition of any previously abnormal staging studies including appropriate biopsies. Patients who were considered to be free of disease after restaging, were designated to be in CR. Patients who failed to achieve a clinical CR but showed a greater than $50 \%$ reduction in clinically 
measurable disease for at least one month were designated to be in partial remission (PR). No response (NR) comprised progressive disease, transient disease regression, or early death.

The overall survival curve was calculated from the date of initial treatment to the date of death or the date of the last follow-up. The actuarial survival curve was constructed according to the KaplanMeier method for nonparametric estimation from incomplete observations (16). The generalized Wilcoxon test was used to evaluate statistical differences between pairs of curves (17).

\section{Anti-HTLV-I antibody}

Sera from 5 patients were screened for antiHTLV-I antibody by ELISA and PA methods at Special Reference Laboratories in Tokyo, Japan.

\section{RESULTS}

All 25 patients with NHL with T-cell phenotype in the present study were diagnosed as having peripheral T-cell lymphoma (PTCL) histopathologically. Ten patients were classified as having a low grade histology according to the criteria by Suchi et al (12). Eleven were classified as high grade histology and the remaining 4 were unclassifiable (Tables 1 (a)-(c)).

\section{Low grade histology}

Histologically, 10 patients were classified as follows: lymphoepithelioid (Lennert's), 1; T-zone, 1; pleomorphic, small, 1; angioimmunoblastic (AILD), 7. Angioimmunoblastic (AILD) type was included here because of the presence of focal or sheet-like proliferation of pale cell or clear cell (12) in addition to the peculiar histologic features of AILD (18). Recent immunohistochemical studies (19) disclosed that the lesions described as AILD comprised peripheral T-cells with a single phenotype. And DNA analyses revealed that the proliferating cell population with peripheral T-cell phenotype was actually a clonal T-cell proliferation based on the evidences of the rearrangement of T-cell receptor $\beta$ chain gene $(20,21)$. Nine patients $(90 \%)$ had an advanced disease and 6 out of the 7 stage IV patients had B symptoms. Multinodal disease was seen in all of the stage IV patients, and liver involvement in 6 with either peripheral blood involvement (3 patients) or bone marrow metastasis ( 2 patients). The patient with pleomorphic, small cell lymphoma had multiple cutaneous nodules without leukemic blood picture. An elevated level of serum LDH and/or ALP was seen in 6 patients $(60 \%)$.

Patients with AILD were remarkable for the advanced disease in all, an elevated level of LDH and/or ALP in 5 and an increased level of serum

Table 1. Clinicopathologic features of patients with peripheral T-cell lymphoma.

(a) Low grade histology

\begin{tabular}{|c|c|c|c|c|c|c|c|c|c|c|}
\hline \multirow[b]{2}{*}{ Case } & \multirow[b]{2}{*}{ Age/Sex } & \multirow{2}{*}{$\begin{array}{l}\text { Histologic } \\
\text { diagnosis }\end{array}$} & \multirow{2}{*}{$\begin{array}{l}\text { Clinical } \\
\text { stage }\end{array}$} & \multicolumn{2}{|c|}{ Clinical presentation } & \multirow{2}{*}{$\begin{array}{l}\text { Abnormal } \\
\text { blood tests }\end{array}$} & \multirow[b]{2}{*}{ HTLV-I } & \multirow{2}{*}{$\begin{array}{l}\text { T-cell } \\
\text { subset }\end{array}$} & \multirow[b]{2}{*}{ Response } & \multirow[b]{2}{*}{$\begin{array}{l}\text { Survival } \\
\text { (months) }\end{array}$} \\
\hline & & & & Multinodal & $\begin{array}{r}\text { Extranodal } \\
\text { involvement }\end{array}$ & & & & & \\
\hline 1. & $59 / \mathrm{M}$ & Lennert & $I_{A}$ & $(-)$ & $(-)$ & $(-)$ & & $\mathrm{Th} / \mathrm{i}$ & $\mathrm{CR}$ & $79 \mathrm{~A}$ \\
\hline 2. & $47 / \mathrm{M}$ & T-zone & $\mathrm{IV}_{\mathrm{B}}$ & $(+)$ & liver, $\mathrm{pb}$ & LDH, ALP, IgA & & & $\mathrm{CR}$ & censored \\
\hline 3. & $57 / \mathrm{M}$ & $\begin{array}{l}\text { pleomorph, } \\
\text { small }\end{array}$ & $\mathrm{IV}_{\mathrm{A}}$ & $(+)$ & skin & $(-)$ & & $\mathrm{Th} / \mathrm{i}$ & CR & $82 \mathrm{~A}$ \\
\hline 4. & $48 / \mathrm{M}$ & AILD & $I V_{B}$ & $(+)$ & liver, $\mathrm{pb}$ & Coombs & & $\mathrm{Th} / \mathrm{i}$ & PR & $8 \mathrm{D}$ \\
\hline 5. & $66 / F$ & AILD & $\mathrm{III}_{\mathrm{B}}$ & $(-)$ & $(-)$ & $A L P, \operatorname{Ig} A$ & & & $\mathrm{CR}$ & $24 \mathrm{D}$ \\
\hline 6. & $46 / \mathrm{M}$ & AILD & $\mathrm{IV}_{\mathrm{B}}$ & $(+)$ & liver,bm & LDH, ALP & $(-)$ & $\mathrm{Ts} / \mathrm{c}$ & PR & $21 \mathrm{D}$ \\
\hline 7. & $78 / \mathrm{M}$ & AILD & $\mathrm{IV}_{\mathrm{B}}$ & $(+)$ & $\begin{array}{c}\text { liver, spleen, } \\
\mathrm{bm}\end{array}$ & L.DH, ALP, Ca & & $\mathrm{Th} / \mathrm{i}$ & NR & $5 \mathrm{D}$ \\
\hline 8. & $70 / \mathrm{F}$ & AILD & $\mathrm{IV}_{\mathrm{B}}$ & $(+)$ & liver & $\mathrm{LDH}, \operatorname{Ig} \mathrm{A}$ & & & NR & $5 \mathrm{D}$ \\
\hline 9. & $77 / \mathrm{M}$ & AILD & $\mathrm{III}_{\mathrm{A}}$ & $(+)$ & $(-)$ & LDH, IgM & & & NR & $13 \mathrm{D}$ \\
\hline 10. & $73 / \mathrm{M}$ & AILD & $\mathrm{IV}_{\mathrm{B}}$ & $(+)$ & liver, $\mathrm{pb}$ & $\operatorname{Ig} G$ & & $\mathrm{Th} / \mathrm{i}$ & $\mathrm{CR}$ & $36 \mathrm{~A}$ \\
\hline
\end{tabular}

pb, peripheral blood; bm, bone marrow; LDH, lactate dehydrogenase; ALP, alkaline phosphatase; Ig, immunoglobulin; Ca, calcium; CR, complete remission; PR, partial remission; NR, no response; a, alive; d, deceased. 
Table 1. (continued)

(b) High grade histology

\begin{tabular}{|c|c|c|c|c|c|c|c|c|c|c|}
\hline Case & Age/Sex & $\begin{array}{l}\text { Histologic } \\
\text { diagnosis }\end{array}$ & $\begin{array}{l}\text { Clinical } \\
\text { stage }\end{array}$ & $\begin{array}{l}\text { Clinical } \\
\text { Multinodal }\end{array}$ & $\begin{array}{l}\text { resentation } \\
\text { Extranodal } \\
\text { involvement }\end{array}$ & $\begin{array}{l}\text { Abnormal } \\
\text { blood tests }\end{array}$ & HTLV-I & $\begin{array}{l}\text { T-cell } \\
\text { subset }\end{array}$ & Response & $\begin{array}{l}\text { Survival } \\
\text { (months) }\end{array}$ \\
\hline 1. & $74 / \mathrm{M}$ & $\begin{array}{l}\text { pleomorph, } \\
\text { medium }\end{array}$ & $\mathrm{IV}_{\mathrm{B}}$ & $(+)$ & pleura & $\begin{array}{l}\text { Coombs, } \\
\text { anf, IgA }\end{array}$ & & & PR & $4 \mathrm{D}$ \\
\hline 2. & $55 / \mathrm{M}$ & $\begin{array}{l}\text { pleomorph, } \\
\text { medium }\end{array}$ & $\mathrm{IV}_{\mathrm{B}}$ & $(-)$ & liver & LDH, ALP & & & PR & $26 \mathrm{D}$ \\
\hline 3. & $47 / F$ & $\begin{array}{l}\text { pleomorph, } \\
\text { medium }\end{array}$ & $\mathrm{IV}_{\mathrm{B}}$ & $(-)$ & $\begin{array}{l}\text { liver, spleen, } \\
\text { pleura }\end{array}$ & $(-)$ & & & PR & $8 \mathrm{D}$ \\
\hline 4. & $46 / \mathrm{M}$ & $\begin{array}{l}\text { pleomorph, } \\
\text { medium }\end{array}$ & $\mathrm{IV}_{\mathrm{A}}$ & $(-)$ & skin & $\mathrm{LDH}$ & $(+)$ & $\mathrm{Th} / \mathrm{i}$ & NR & $9 \mathrm{D}$ \\
\hline 5. & $46 / \mathrm{M}$ & $\begin{array}{l}\text { pleomorph, } \\
\text { medium }\end{array}$ & $\mathrm{II}_{\mathrm{A}}$ & $(-)$ & waldeyer & $\operatorname{Ig} M$ & $(-)$ & $\mathrm{Th} / \mathrm{i}$ & $\mathrm{CR}$ & $38 \mathrm{~A}$ \\
\hline 6. & $65 / F$ & $\begin{array}{l}\text { pleomorph, } \\
\text { large }\end{array}$ & $\mathrm{IV}_{\mathrm{A}}$ & $(+)$ & $\mathrm{bm}, \mathrm{pb}$, liver & $\underset{\mathrm{Ca}}{\mathrm{LDH}, \mathrm{ALP}}$ & $(+)$ & $\mathrm{Th} / \mathrm{i}$ & PR & $7 \mathrm{D}$ \\
\hline 7. & $42 / \mathrm{M}$ & $\begin{array}{l}\text { immuno- } \\
\text { blastic }\end{array}$ & $\mathrm{IV}_{\mathrm{A}}$ & $(+)$ & liver & LDH, ALP & & $\mathrm{Th} / \mathrm{i}$ & CR & $23 \mathrm{D}$ \\
\hline 8. & $49 / \mathrm{M}$ & immuno- & $\mathrm{IV}_{\mathrm{B}}$ & $(+)$ & $\begin{array}{l}\text { liver, pleura, } \\
\mathrm{pb}\end{array}$ & $\begin{array}{l}\mathrm{ALP}, \mathrm{Ca} \\
\operatorname{IgA}\end{array}$ & & $\mathrm{Th} / \mathrm{i}$ & NR & $3 \mathrm{D}$ \\
\hline 9. & $56 / \mathrm{M}$ & $\begin{array}{l}\text { immuno- } \\
\text { blastic }\end{array}$ & $\mathrm{IV}_{\mathrm{A}}$ & $(-)$ & $\begin{array}{l}\text { liver, pleura, } \\
\text { skin }\end{array}$ & $(-)$ & & & NR & $5 \mathrm{D}$ \\
\hline 10. & $44 / F$ & $\begin{array}{l}\text { immuno- } \\
\text { blastic }\end{array}$ & $I_{\mathrm{A}}$ & $(-)$ & $\mathrm{bm}$ & $\operatorname{Ig} M$ & & $\mathrm{Ts} / \mathrm{c}$ & CR & $36 \mathrm{D}$ \\
\hline 11. & $57 / \mathrm{M}$ & $\begin{array}{l}\text { immuno- } \\
\text { blastic }\end{array}$ & $\mathrm{III}_{\mathrm{A}}$ & $(+)$ & $(-)$ & $\mathrm{LDH}$ & & $\mathrm{Th} / \mathrm{i}$ & PR & $52 \mathrm{D}$ \\
\hline
\end{tabular}

bm, bone marrow; pb, peripheral blood; anf, antinuclear factor; Ig, Immunoglobulin; LDH, lactate dehydrogenase; ALP, alkaline phosphatase; $\mathrm{Ca}$, calcium; $\mathrm{CR}$, complete remission; PR, partial remission; NR, no response; a, alive; d, deceased.

(c) Unclassifiable

\begin{tabular}{|c|c|c|c|c|c|c|c|c|c|c|}
\hline Case & Age/Sex & $\begin{array}{l}\text { Histologic } \\
\text { diagnosis }\end{array}$ & $\begin{array}{l}\text { Clinical } \\
\text { stage }\end{array}$ & $\begin{array}{l}\text { Clinical } \\
\text { Multinodal }\end{array}$ & $\begin{array}{l}\text { Exesentation } \\
\text { Extranodal } \\
\text { involvement }\end{array}$ & $\begin{array}{l}\text { Abnormal } \\
\text { blood tests }\end{array}$ & HTLV-I & $\begin{array}{l}\text { T-cell } \\
\text { subset }\end{array}$ & Response & $\begin{array}{l}\text { Survival } \\
\text { (month) }\end{array}$ \\
\hline 1. & $38 / F$ & $\begin{array}{l}\text { angio- } \\
\text { centric }\end{array}$ & $\mathrm{III}_{\mathrm{A}}$ & $(-)$ & nose & $(-)$ & & & $C R$ & $78 \mathrm{~A}$ \\
\hline 2. & $49 / \mathrm{M}$ & $\begin{array}{l}\text { angio- } \\
\text { centric }\end{array}$ & $\mathrm{IV}_{\mathrm{B}}$ & $(-)$ & nose, liver & LDH, ALP & & $\mathrm{Th} / \mathrm{i}$ & NR & $4 \mathrm{D}$ \\
\hline 3. & $29 / \mathrm{M}$ & $\begin{array}{l}\text { angio- } \\
\text { centric }\end{array}$ & $\mathrm{IV}_{\mathrm{B}}$ & $(-)$ & palate, bm & $(-)$ & & & PR & $11 \mathrm{D}$ \\
\hline 4. & $73 / \mathrm{M}$ & $\begin{array}{l}\text { angio- } \\
\text { centric }\end{array}$ & $I V_{B}$ & $(-)$ & $\begin{array}{l}\text { paranasal } \\
\text { sinus, liver }\end{array}$ & $\underset{\text { IgA }}{\mathrm{LDH}, \mathrm{ALP}}$ & $(-)$ & $\mathrm{Th} / \mathrm{i}$ & NR & $6 \mathrm{D}$ \\
\hline
\end{tabular}

bm, bone marrow; LDH, lactate dehydrogenase; ALP, alkaline phosphatase; CR, complete remission; $\mathrm{PR}$, partial remission; NR, no response; a, alive; d, deceased.

immunoglobulins in 4.

Dominant phenotype was CD4 in 5 including 3 AILD patients and was CD8 in 1. Nine patients with advanced disease received chemotherapy as an initial treatment. CR was obtained in 4 (44\%), PR in 2 $(22 \%)$ and NR in $3(33 \%)$. One CR patient was lost to follow-up subsequently and another relapsed and died. All of PR and NR patients have died, thus leaving only $2 \mathrm{CR}$ patients and 1 stage IA patient treated with radiochemotherapy alive currently.

\section{High grade histology}

Eleven patients were included in this category. There were: pleomorphic, medium sized, 5; pleomorphic, large cell, 1; and immunoblastic, 5 . Ten patients $(91 \%)$ had an advanced disease but B 
symptoms were seen in only 4 out of 9 stage IV patients. Multinodal disease was seen less frequent in patients with high grade histology $(45 \%)$ than in patients with low grade histology $(80 \%)$. Extranodal involvement in 9 stage IV patients was noted in liver (6 patients, $67 \%$ ), pleura (4 patients, $44 \%$ ), bone marrow and/or peripheral blood (3 patients, $33 \%$ ) and skin (2 patients, 22\%). An elevated LDH and/or ALP level was noted in 6 out of 11 patients with high grade histology $(54 \%)$.

In 2 patients with pleomorphic histology, positive reactivity against HTLV-I was noted and was considered to support the diagnosis of ATLL. Dominant phenotype was CD4 in 6 patients including 2 ATLL patients and was CD8 in 1 . Ten patients with advanced disease received chemotherapy as an initial treatment. Two patients had attained a CR (20\%), which was followed by a relapse and death. Five PR $(50 \%)$ and 3 NR (30\%) patients died, thus leaving no patient with advanced disease alive. One stage IIA patient was treated with radiochemotherapy successfully and is currently alive and well.

\section{Unclassifiable}

Four patients including 3 patients with nasal T-cell lymphoma (22) and 1 patient with primary lesion in the upper palate were unclassifiable within the criteria by Suchi et al (12). The histopathologic findings of these 4 patients were considered to be consistent with the criteria of Jaffe (6) with reference to angiocentric lymphoma. All patients had an advanced disease. In spite of the minimal nodal disease, three patients had a metastasis to the liver or bone marrow from the beginning. Two patients with liver involvement were noted to have an elevated LDH and ALP level.

Dominant phenotype was CD4 in 2 patients studied. All 4 patients received chemotherapy as a remission induction treatment, however, no stage IV patients attained a CR. One stage IIIA patient was successfully treated with chemoradiotherapy and is currently alive and well.

\section{Survival}

With a mean follow-up of 23 months (range 3 to 82 months), 19 patients have died, 1 was lost to follow-up, 4 are alive without disease and the remaining 1 is living with disease. The survival of all
25 patients is shown in Fig. 1. Median survival is 13 months with the projected actuarial survival is $25 \%$ at 4 years.

Figure 2 shows survival curves for patients according to their response to remission induction treatment. Sixty-three percent of the complete responders are predicted to be alive at 4 years, whereas only $13 \%$ of the partial responders and none of the nonresponders are predicted to survive at 4 years. Median survivals for PR and NR patients were 11 months and 5 months, respectively. CR patients had a significantly longer survival than $P R$ and NR patients $(\mathrm{p}<0.01)$.

Figure 3 shows survival curves of patients by grade of malignancy defined by Suchi et al (12). Thirty-three percent of the patients with low grade

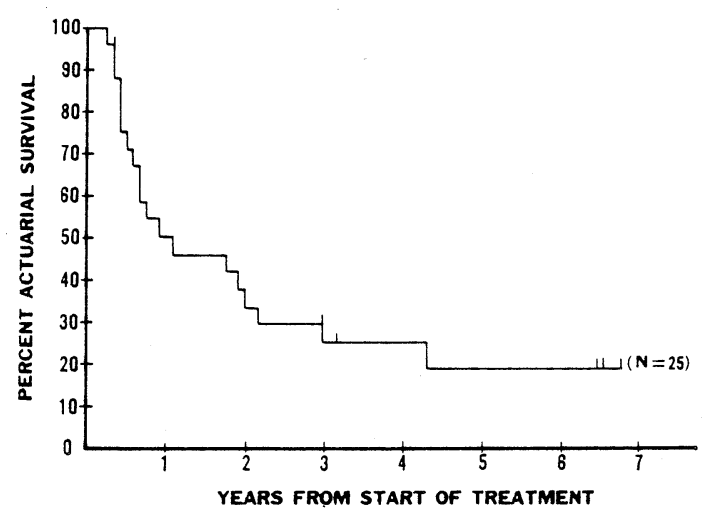

Fig. 1. Survival of all 25 patients from the initiation of therapy. The tick marks indicate patients alive at that interval.

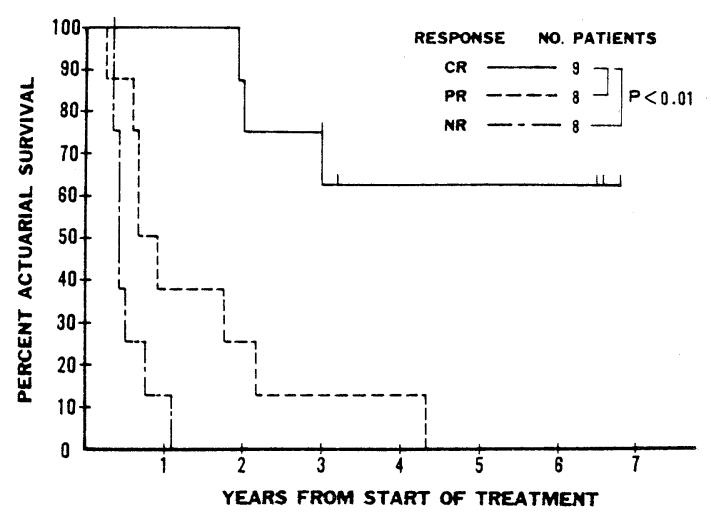

Fig. 2. Survival curves for patients according to their response to initial therapy. The tick marks indicate patients alive at that interval. CR, complete remission; $\mathrm{PR}$, partial remission; NR, no response. 
histology, $18 \%$ of those with high grade histology and $25 \%$ of those with unclassifiable histology are predicted to be alive at 4 years, respectively. Median survivals were 21 months for low grade histology, 9 months for high grade histology and 11 months for unclassifiable histology, respectively. However, there was no statistical significance between the grades classified according to Suchi's criteria (12).

\section{Prognostic indicators of survival}

Twelve clinicopathologic factors, determined at the time of diagnosis, were assessed for their relationship to survival of the 24 patients (one patient who had been lost to follow-up was excluded). Factors adversely affected survival were stage IV as compared to stages I, II and III (survival at 4 years

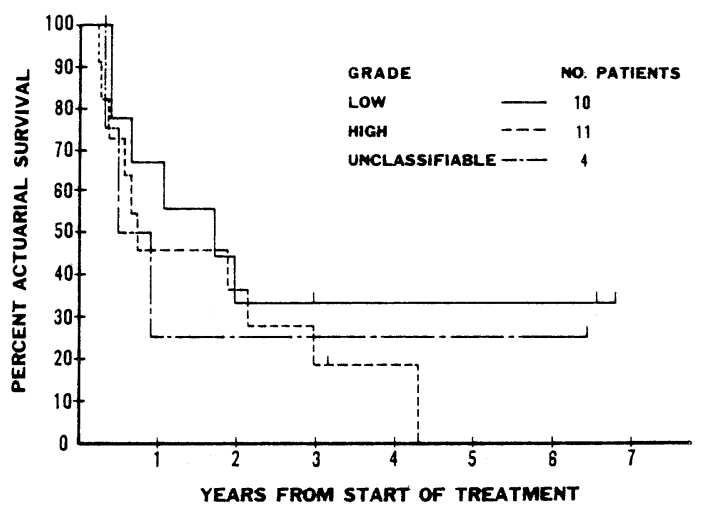

Fig. 3. Survival of patients by grade of malignancy according to Suchi's classification (12). The tick marks indicate patients alive at that interval.

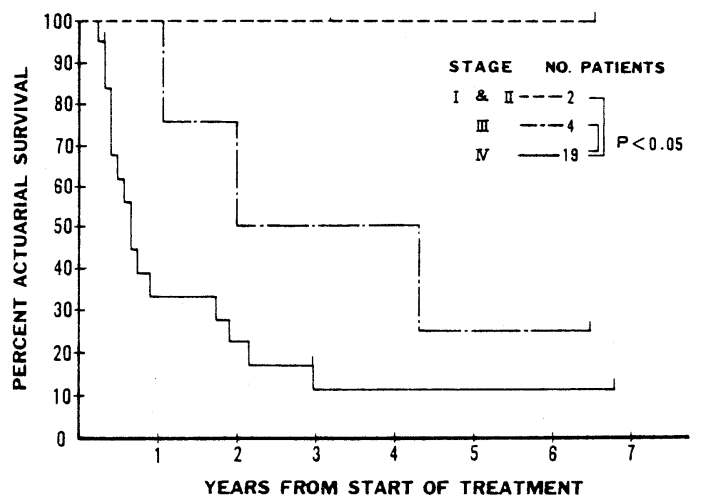

Fig. 4. Survival of patients by initial clinical stage. The tick marks indicate patients alive at that interval. were $11 \%$ for stage IV, $100 \%$ for stages I and II, and $50 \%$ for stage III, p<0.05) (Fig. 4), presence of B symptoms (survival at 4 years were $8 \%$ for patients with B symptoms and $45 \%$ for those without B symptoms, $\mathrm{p}<0.05$ ), liver involvement (survival at 4 years were $8 \%$ for patients with liver metastasis and $45 \%$ for those without liver: metastasis, $\mathrm{p}<0.05$ ), malignant pleural effusion (survival at 4 years were $0 \%$ for patients with pleural effusion and $30 \%$ for those without effusion, $\mathrm{p}<0.05$ ) and more than 2 extranodal sites of involvement (survival at 4 years were $9 \%$ for patients with more than 2 extranodal disease and $38 \%$ for those with less than 1 extranodal disease, $\mathrm{p}<0.05$ ). Single factors that did not adversely affect survival were age, sex, multiple nodal disease, bone marrow involvement, high LDH and/or ALP level, helper phenotype, and histologic subtype.

\section{DISCUSSION}

Histopathologic diagnoses of all 25 patients with NHL with T-cell phenotype in our institution were those included in the collective term, PTCL, and comprised Lennert's lymphoma, T-zone lymphoma, pleomorphic small, medium or large cell lymphoma, angioimmunoblastic lymphoma, immunoblastic lymphoma and angiocentric lymphoma. Heterogeneous as histologic diagnoses of PTCL were, their clinical behaviors were rather consistent, namely, aggressive, refractory to treatment, and accordingly, prognostically poor. In fact, patients with PTCL in the present study were endowed with clinicopathologic factors which have been noted to adversely affect survival (23), needless to say, aside from T-cell phenotype. Such prognostic factors included age (32\% of patients were older than 60 years old), stage ( $92 \%$ of patients had an advanced disease), B symptoms ( $56 \%$ ), multinodal disease $(52 \%)$, liver involvement $(56 \%)$, bone marrow and/or peripheral blood involvement (36\%), malignant pleural effusion (16\%), and elevated serum LDH level (48\%). Actually, factors such as stage IV, B symptoms, and extranodal disease involving liver and/or pleura were recognized to adversely affect survival among patients with PTCL in the present study with a statistical significance.

The response to treatment was quite discouraging. CR was obtained in 7 out of 23 patients 
(30\%) with advanced disease, but 3 out of $6 \mathrm{CR}$ patients relapsed subsequently and 1 was lost to follow-up. Thus, 19 out of 22 patients with advanced disease $(86 \%)$ have died. In this regard, recent report by Coiffier (24) disclosed that intensive regimens such as LNH-80 gave better results for PTCL than conventional doses of adriamycin-based regimens by obtaining a large number of CRs.

Suchi and Lennert proposed a new histologic classification of T-cell lymphoma (12), in which they classified PTCL into 2 groups according to the cytologic distinction of the principal component of the tumor. They insist that the division of T-cell lymphomas into the 2 major categories of low and high grade does not necessarily reflect the grade of aggressiveness in their clinical behavior (12). However, histopathologic classifications would not be evaluated until they are recognized to have a clinical correlation. Although the significance of classifying PTCL into low and high grade categories has been obscure in the present study, further studies performed on a larger number of patients might admit the clinicopathologic correlation of their classification. When applying their classification, we could not find appropriate histologic subtypes for pleomorphic mixed cell lymphoma of LSG classification (25), so-called nasal T-cell lymphoma (22), and diffuse lymphoma with T-cell phenotype but without pleomorphic morphology. Suchi, et al, seemed to dissect ATLL into 3 histologic subtypes based on cytologic morphology in their classification. In our opinion, ATLL should be separated from other morphology-based subtypes because of its unique and distinctive clinicopathologic entity associated with the human retrovirus HTLV-I (26).

Jaffe (6) insisted in her review on the necessity of separating ATLL (7), IBL-like T-cell lymphoma (8) and angiocentric lymphoma (22) from other PTCL.

We consider it inappropriate to classify PTCL, which has a mature T-cell phenotype in common but encompasses a broad spectrum of cytologic subtypes on the one hand and some unique distinctive clinicopathologic entities on the other, solely on the morphologic basis. New classification of PTCL, which warrants coexistence of morphology based lymphomas such as Lennert's, T-zone and so on and the lymphomas with established clinicopathologic entities, should be elaborated here in Japan, where PTCL is more common than anywhere in the world.

\section{REFERENCE}

1) Kadin ME, Berard CW, Nanba $\mathrm{K}$, et al: Lymphoproliferative diseases in Japan and Western countries: Proceedings of the United States-Japan seminar, September 6 and 7, 1982, in Seattle, Washington. Hum Pathol 14: 745, 1983.

2) Kikuchi M, Mitsui T, Matsui N, et al: T-cell malignancies in adults: Histopathological studies of lymph nodes in 110 patients. Jpn J Clin Oncol 9: (Suppl): 407, 1979.

3) Watanabe $S$, Nakajima $T$, Shimosato $Y$, et al: $T$-cell malignancies: Subclassification and interrelationship. Jpn J Clin Oncol 9 (Suppl): 423, 1979.

4) Greer JP, York JC, Cousar JB, et al: Peripheral T-cell lymphoma: A clinicopathologic study of 42 cases. J Clin Oncol 2: 788, 1984.

5) Suchi T, Tajima K: Peripheral T-cell malignancy as a problem in lymphoma classification. Jpn J Clin Oncol 9 (Suppl): 443, 1979.

6) Jaffe ES: Pathologic and clinical spectrum of postthymic T-cell malignancies. Cancer Invest 2: 413, 1984.

7) Uchiyama T, Yodoi J, Sagawa K, et al: Adult T-cell leukemia: Clinical and hematologic features of 16 cases. Blood 50: 481, 1977.

8) Shimoyama M, Minato $\mathrm{K}$, Saito $\mathrm{H}$, et al: Immunoblastic lymphadenopathy (IBL)-like T-cell lymphoma. Jpn J Clin Oncol 9 (Suppl): 347, 1979.

9) Lennert K, Mohri N, Stein H, et al: The histopathology of malignant lymphoma. Br J Haematol 31 (Suppl): 193, 1975.

10) Lennert K, Mohri N, Stein H, et al: Malignant lymphomas other than Hodgkin's disease. in: HistologyCytology-Ultrastructure-Immunology. Springer Verlag, Berlin, 1978.

11) Non-Hodgkin's Lymphoma Pathologic Classification Project. National Cancer Institute sponsored study of classifications of non-Hodgkin's lymphoma: Summary and description of a working formulation for clinical usage. Cancer 49: 2112, 1982.

12) Suchi T, Lennert K, Tu Ly, et al: Histopathology and immunohistochemistry of peripheral T-cell lymphomas: a proposal for their classification. J Clin Pathol 40: 995, 1987.

13) Carbone PP, Kaplan HS, Musshoff K, et al: Report of the committee on Hodgkin's disease staging classification. Cancer Res 31: 1860, 1971.

14) Kaplan ME, Clark C: An improved rosetting assay for detection of human $\mathrm{T}$ lymphocytes. J Immunol Meth 5: $131,1974$.

15) Shimizu K, Hara K, Kunii A: Evaluation of the response of advanced diffuse large cell lymphomas (LSG classification) to weekly CHOP therapy. Jpn J Clin Hematol 30: 309, 1989 (in Japanese).

16) Kaplan E, Meier P: Nonparametric estimation from in- 
complete observations. J Am Stat Assoc 53: 457, 1958.

17) Gehan E: A generalized Wilcoxon test for comparing arbitrarily singly-censored samples. Biometrika 52: 203, 1965.

18) Frizzera G, Moran EM, Rappaport H: Angioimmunoblastic lymphadenopathy with dysproteinemia. Lancet i: 1070, 1974.

19) Namikawa $R$, Suchi $T$, Ueda $R$, et al: Phenotyping of proliferating lymphocytes in angioimmunoblastic lymphadenopathy and related lesions by the double immunoenzymatic staining technique. Am J Pathol 127: 279, 1987.

20) Weiss LM, Strickler JG, Dorfman RF, et al: Clonal $\mathrm{T}$-cell proliferations in angioimmunoblastic lymphadenopathy and angioimmunoblastic lymphadenopathylike lymphoma. Am J Pathol 122: 392, 1986.

21) Tobinai $K$, Minato $K$, Ohtsu $T$, et al: Clinicopathologic, immunophenotypic, and immunogenotypic analyses of immunoblastic lymphadenopathy-like T-cell lymphoma.
Blood 72: 1000, 1988.

22) Ishii $Y$, Yamanaka $N$, Ogawa $K$, et al: Nasal T-cell lymphoma as a type of so-called "lethal midline granuloma”. Cancer 50: 2336, 1982.

23) Todd MB, Portlock CS, Farber LR, et al: Prognostic indicators in diffuse large cell (histiocytic) lymphoma. Int J Radiat Oncol Biol Phys 12: 593, 1986.

24) Coiffier B, Berger F, Bryon PA, et al: T-cell lymphomas: Immunologic, histologic, clinical, and therapeutic analysis of 63 cases. J Clin Oncol 6: 1584, 1988.

25) Suchi T, Tajima K, Nanba K, et al: Some problems on the histopathological diagnosis of non-Hodgkin's malignant lymphoma. A proposal of a new type. Acta Pathol Jpn 29: 755, 1979.

26) Jaffe ES, Cossman J, Blattner WA, et al: The pathologic spectrum of adult T-cell leukemia/lymphoma in the United States. Am J Surg Pathol 8: 263, 1984. 